\title{
IMPLEMENTASI UU WAKAF DALAM PENYELESAIAN SENGKETA WAKAF DI WILAYAH PESISIR JAWA TENGAH
}

\author{
Islamiyati*, Ahmad Rofiq, Ro'fah Setyowati, Dewi Hendrawati \\ Fakultas Hukum Universitas Diponegoro Semarang \\ Jl. Prof. Soedarto, SH. No.1 Semarang, 50275 \\ islamiyati@yahoo.co.id
}

\begin{abstract}
Wakaf practice in the northern community of Central Java region, which is not in accordance with the rules of Wakaf Law, thus causing wakaf law disputes, making this research important to do. The research will analyze how the implementation of Article 62 of Law No. 41/2004 in the settlement of wakaf disputes in Central Java in 2016. The benefits will reveal and analyze the case of endowment disputes and their model of settlement. The type of this research field research with research samples Kendal District, Demak and Semarang City. The method used is the empirical juridical.The result of the research shows that the settlement of wakaf disputes in Northern Central Java uses the method according to Article 62 of the Wakaf Law, namely litigation and non litigation lane. The parties mostly use non-litigation channels through deliberation (23\%) mediation (60.8\%).
\end{abstract}

Keywords: UU Wakaf; Wakaf Law; Dispute Settlement; Central Java

\begin{abstract}
Abstrak
Praktek wakaf di masyarakat bagian utara wilayah Jawa Tengah menimbulkan sengketa hukum wakaf. Penelitian menganalisis implementasi Pasal 62 UU No. 41/2004 dalam penyelesaian sengketa wakaf di Jawa Tengah tahun 2016 dan model penyelesaiannya. Jenis penelitian field research dengan sampel penelitian dari wilayah Kabupaten Kendal, Demak dan Kota Semarang. Metode pendekatan yang digunakan adalahyuridis empiris. Hasil penelitian menunjukkan penyelesaian sengketa wakaf di daerah Jawa Tengah Bagian Utara menggunakan metode sesuai Pasal 62 UU Wakaf, yakni jalur litigasi dan non litigasi. Para pihak lebih banyak menggunakan jalur non litigasi melalui musyawarah $(23 \%)$ dan melalui mediasi $(60,8 \%)$.
\end{abstract}

Kata Kunci: UU Wakaf; Hukum Wakaf; Penyelesaian Sengketa; Jawa Tengah

\section{A. Pendahuluan}

Penelitian ini berlatar belakang dari maraknya sengketa wakaf di masyarakat Jawa Tengah Bagian Utara, misalnya; dimintanya kembali tanah wakaf oleh ahli waris wakif, tanah wakaf dikuasai secara turun temurun oleh nadzir yang penggunaannya menyimpang dari akad wakaf, adanya tanah wakaf yang diminta kembali oleh ahli waris wakif setelah wakif meninggal dunia. Selain itu, sengketa wakaf juga terjadi pada nadzir yang tidak bertanggung jawab atas kewajibannya, seperti; harta benda wakaf tidak terpelihara sebagaimana mestinya dan terlantar atau beralih ke tangan pihak ketiga dengan cara melawan hukum (Hafsah, 2009).

Sengketa hukum wakaf adalah permasalahan hukum yang terjadi antara dua pihak atau lebih, dimana masing-masing pihak tidak melaksanakan kewajibannya dan pihak lain merasa dirugikan, sehingga tujuan dan peruntukan wakaf tidak tercapai (Fadhilah, 2011). Wakaf adalah perbuatan hukum, karena di dalamnya ada subyek 
wakaf (wakif), obyek wakaf (harta wakaf), lembaga penyelesaian sengketa wakaf (Pengadilan Agama), dan dasar aturan hukumnya (Al-Qur'an, Al-Hadist dan Ijtihad). Sebagai tindakan hukum yang berkaitan dengan kepentingan publik, wakaf memiliki potensi munculnya pelanggaran, baik yang dilakukan oleh nadzir sebagai pengelola, ahli waris wakif, maupun oleh pihak lain. Dengan demikian, secara nyata wakaf yang terjadi dalam kehidupan masyarakat belum sepenuhnya berjalan tertib dan efisien. Penyebabnya dapat dilihat melalui tabel sebagai berikut :

\section{Tabel 1.}

Penyebab Sengketa atau Konflik Perwakafan

\begin{tabular}{ll}
\hline $\begin{array}{l}\text { Persyaratan } \\
\text { Wakaf }\end{array}$ & $\begin{array}{l}\text { Terkait dengan sah atau } \\
\text { tidaknya wakaf dan } \\
\text { batalnya wakaf }\end{array}$ \\
\hline $\begin{array}{l}\text { Tidak } \\
\text { Jelasnya }\end{array}$ & $\begin{array}{l}\text { Status ukuran dan luas } \\
\text { benda wakaf }\end{array}$ \\
Keluarga & $\begin{array}{l}\text { Ahli waris tidak } \\
\text { mengetahui adanya }\end{array}$ \\
& $\begin{array}{l}\text { ikrar wakaf } \\
\text { Menarik kembali harta } \\
\text { benda wakaf, sikap } \\
\text { serakah ahli waris }\end{array}$ \\
Ahli Waris & Menyalahgunakan \\
& $\begin{array}{l}\text { peruntukan dan fungsi } \\
\text { harta wakaf }\end{array}$ \\
Nadzir &
\end{tabular}

\section{Data diolah dari Data Sekunder}

Ibrahim Siregar dalam penelitiannya tentang Penyelesaian Sengketa Wakaf Di Indonesia: Pendekatan Sejarah Sosial Hukum Islam (2017) menjelaskan bahwa permasalahan yang terjadi pada awal periode Islam dan kasus-kasus kontemporer tentang sengketa wakaf disebabkan oleh perubahan sosial; pergeseran nilai dan tatanan masyarakat. Selain itu, juga tidak adanya bukti tertulis yang menyatakan bahwa status suatu harta sebagai objek wakaf. Penyelesaiannya melalui musyawarah yang dipimpin oleh tokoh agama dan tokoh masyarakat setempat (Siregar, 2012).

Junaidi Abdullah dan Nur Qodin, dalam penelitiannya yang berjudul Penyelesaian Sengketa Wakaf dalam Hukum Positif (2014), menjelaskan bahwa penyelesaian sengketa wakaf dalam hukum positif di Indonesia ada dua, yakni melalui jalur litigasi dan non litigasi. Non litigasi meliputi musyawarah, mediasi dan arbritase, sedangkan jalur litigasi melalui proses hukum di Pengadilan Agama (Abdullah, 2014).

Tata cara dan prosedur penyelesaian sengketa perwakafan menurut BAB VII Pasal 62 Undang-Undang Wakaf adalah: (1) Penyelesaian sengketa perwakafan ditempuh melalui musyawarah untuk mencapai mufakat; (2) Apabila penyelesaian sengketa sebagaimana dimaksud pada ayat (1) tidak berhasil, sengketa dapat diselesaikan melalui mediasi, arbitrase, atau pengadilan (Pengadilan Agama).

Berdasarkan paparan di atas, apabila dianalisis, terdapat legal issue atau permasalahan hukum yang berupa kesenjangan antara das sein dan das sollen. Das sollen dalam penelitian ini adalah aturan hukum wakaf yang terdapat dalam peraturan perundang-undangan. Das sein dalam penelitian ini adalah masih banyak praktek wakaf di masyarakat wilayah Jawa Tengah Bagian Utara yang tidak sesuai dengan aturan UU Wakaf, sehingga menimbulkan permasalahan, kemudian konflik yang akhirnya menjadi sengketa wakaf.

Pada penelitian ini, fokus permasalahannya adalah implementasi UU Wakaf No. 41 Tahun 2004 Pasal 62 dalam penyelesaian sengketa wakaf di Jawa Tengah. Penelitian ini dilakukan di Bagian Utara Jawa Tengah, dengan mengambil sampel beberapa kabupaten atau kota di Jawa Tengah, seperti; Semarang, Demak, dan Kendal. Penelitian ini juga membatasi sengketa wakaf harta tetap (tanah) yang terjadi di obyek penelitian. 
Tujuan penelitian untuk menganalisis implementasi Pasal 62 UU Wakaf No. 41 Tahun 2004 dalam penyelesaian sengketa wakaf di Jawa Tengah bagian utara. Manfaatnya dapat menghasilkan metode penyelesaian sengketa wakaf bagi yang memerlukannya, sehingga tercapai tujuan wakaf dan dapat digunakan sebagai rujukan bagi penelitian selanjutnya yang berkaitan dengan sengketa wakaf.

\section{B. Metode Penelitian}

Jenis penelitian ini adalah field research (penelitian lapangan) yang mengambil lokasi di Wilayah Jawa Tengah Bagian Utara. Beberapa daerah di wilayah Jawa Tengah yang menjadi sampel penelitian adalah Semarang, Demak, dan Kendal. Tradisi penelitiannya menggunakan kualitatif yang menyertakan analisis kuantitatif untuk melaporkan hasil penelitian, maksudnya data penelitian akan dijelaskan dalam bentuk kalimatdisertai penjelasan angka.

Pendekatan penelitiannya menggunakan pendekatan yuridis empiris. Yuridis artinya pendekatan yang menggunakan kajian perundang-undangan untuk menganalisis penelitian (Soekanto, 1985). Aturan perundang-undangan yang dipakai adalah KHI Inpres No. 1/1991 Buku III, UU No. 41/2004 tentang Hukum Wakaf dan PP No. 42/2006. Sedangkan pendekatan empiris adalah pendekatan penelitian yang berdasarkan data yang diketemukan dalam penelitian lapangan untuk memperoleh pengetahuan lapangan tentang hubungan dan pengaruh hukum terhadap masyarakat (Subagyo, 1991). Penelitian ini juga menggunakan pendekatan ilmu sosial untuk mengetahui sejauhmanakah masyarakat menggunakan hukum wakaf dalam menyelesaikan sengketa wakaf.

Data primer dalam penelitian ini didapatkan dari subyek penelitian (informan) melalui metode wawancara dan dokumentasi. Informannya antara lain; nadzir, wakif, PPAIW, hakim dan para pihak yang bersengketa serta tokah masyarakatyang berhubungan dengan tema penelitian. Penelitian ini menggunakan analisis studi kasus (case study) yang terjadi di masyarakat Jawa Tengah Bagian Utara tentang sengketa wakaf, kemudian ditarik kesimpulan berdasarkan fenomena dan keteraturan penyelesaian kasus yang didapat dari setiap kasus yang diselidiki. Kesimpulan penelitian akan dilakukan dengan menggunakan metode induktif, yakni penarikan kesimpulan dari permasalahan-permasalahan khusus, berupa kasus sengketa wakaf yang terjadi di daerah obyek penelitian, kemudian disimpulkan menjadi pernyataan yang bersifat umum.

\section{Hasil dan Pembahasan}

Data penelitian menunjukkan bahwa kasus sengketa wakaf yang terjadi di Kabupaten Kendal, Demak dan Kota Semarang antara tahun 2006 sampai tahun 2015, beserta faktor penyebab dan penyelesaiannya dapat dijelaskan melalui tabel 2.

Tabel 2.

Kasus Sengketa Wakaf dan Penyelesaiannya (2006-2015) (Hendrawati, 2018)

\begin{tabular}{llrll}
\hline $\begin{array}{l}\text { Wilayah } \\
\text { Terjadinya } \\
\text { Sengketa } \\
\text { Wakaf }\end{array}$ & Kasus & Sengketa & $\begin{array}{l}\text { Faktor } \\
\text { Penyebab } \\
\text { Sengketa Wakaf }\end{array}$ & $\begin{array}{l}\text { Penyelesaian } \\
\text { Sengketa Wakaf }\end{array}$ \\
\hline Kendal & & & & Mediasi \\
& Sengketa terjadi di & Nadzir & \\
& KUA & Kaliwungu & wanprestasi & \\
& Kabupaten Kendal, & kepada wakif & \\
& antara nadzir dengan & & \\
& wakif (2006). & & & \\
\hline
\end{tabular}




\begin{tabular}{|c|c|c|c|}
\hline & $\begin{array}{l}\text { Sengketa terjadi di } \\
\text { Purwosari, } \\
\text { Patebon, KUA } \\
\text { Kendal, antara ahli } \\
\text { waris wakif dengan } \\
\text { nadzir (2006). }\end{array}$ & $\begin{array}{l}\text { Penarikan } \\
\text { kembali tanah } \\
\text { wakaf oleh ahli } \\
\text { waris wakif. }\end{array}$ & Mediasi \\
\hline & $\begin{array}{l}\text { Sengketa terjadi di } \\
\text { Jambearum, KUA } \\
\text { Patebon, Kabupaten } \\
\text { Kendal, nadzir dengan } \\
\text { wakif (2008). }\end{array}$ & $\begin{array}{lr}\text { Sengketa } & \text { wakaf } \\
\text { tentang } & \text { alih } \\
\text { fungsi } & \text { benda } \\
\text { wakaf. } & \end{array}$ & Mediasi \\
\hline & $\begin{array}{l}\text { Sengketa terjadi di } \\
\text { Bandengan, KUA Kota } \\
\text { Kendal, Kabupaten } \\
\text { Kendal, nadzir dan } \\
\text { masyarakat dengan } \\
\text { wakif (2006). }\end{array}$ & $\begin{array}{l}\text { Sengketa wakaf } \\
\text { tentang } \\
\text { perubahan } \\
\text { peruntukan } \\
\text { benda wakaf. }\end{array}$ & Mediasi \\
\hline Semarang & $\begin{array}{l}\text { Sengketa terjadi di } \\
\text { KUA Kecamatan } \\
\text { Mijen, Kota Semarang, } \\
\text { antara ahli waris wakif } \\
\text { dengan nadzir (2006) }\end{array}$ & $\begin{array}{l}\text { Sengketa wakaf } \\
\text { tentang } \\
\text { penggunaan harta } \\
\text { wakaf yang tidak } \\
\text { sesuai dengan } \\
\text { peruntukan harta } \\
\text { wakaf. }\end{array}$ & Mediasi \\
\hline & $\begin{array}{l}\text { Sengketa terjadi di } \\
\text { KUA Kecamatan } \\
\text { Mijen, Kota Semarang, } \\
\text { antara ahli waris wakif } \\
\text { dengan nadzir (2007). }\end{array}$ & $\begin{array}{l}\text { Sengketa wakaf } \\
\text { tentang } \\
\text { penarikan harta } \\
\text { wakaf oleh ahli } \\
\text { waris wakif. }\end{array}$ & Mediasi \\
\hline \multirow[t]{3}{*}{ Demak } & $\begin{array}{l}\text { Sengketa terjadi di } \\
\text { KUA Kecamatan } \\
\text { Mranggen, Kabupaten } \\
\text { Demak, antara nadzir } \\
\text { dengan ahli waris } \\
(2012) \text {. }\end{array}$ & $\begin{array}{l}\text { Sengketa wakaf } \\
\text { sebab harta } \\
\text { wakaf tidak } \\
\text { tersertifikasi. }\end{array}$ & PA Demak \\
\hline & $\begin{array}{l}\text { Sengketa terjadi di } \\
\text { KUA Bonang, Demak } \\
\text { diantara ahli waris } \\
(2015) \text {. }\end{array}$ & $\begin{array}{l}\text { Sengketa wakaf } \\
\text { yang tidak ada } \\
\text { persetujuan ahli } \\
\text { waris. }\end{array}$ & Musyawarah \\
\hline & $\begin{array}{l}\text { Sengketa terjadi di } \\
\text { KUA Bonang, Demak } \\
\text { antara ahli waris } \\
\text { dengan nadzir (2015). }\end{array}$ & $\begin{array}{l}\text { Sengketa wakaf } \\
\text { tentang } \\
\text { peruntukan harta } \\
\text { wakaf }\end{array}$ & Musyawarah \\
\hline
\end{tabular}


Berdasarkan data tabel di atas, dapat dijelaskan bahwa di setiap daerah mesti ada sengketa wakaf, baik di Kendal, Semarang, maupun Demak, adapun macam-macam sengketa wakaf yang terjadi adalah; (1) Nadzir wanprestasi kepada wakif, nadzir tidak menepati janji pada wakif tentang peruntukan dan penggunaan harta wakaf; (2) Harta wakaf tidak tersertifikasi, harta wakaf yang berupa tanah tidak ada sertifikat wakafnya, sehingga tidak ada bukti otentik telah terjadi perbuatan hukum wakaf; (3) Penarikan kembali harta wakaf oleh wakif, wakif menarik kembali harta wakaf dan membatalkan perbuatan wakafnya; (4) Penarikan kembali tanah wakaf oleh ahli waris wakif, karena alasan ekonomi; (5) Alih fungsi benda wakaf, harta wakaf fungsinya dialihkan pada yang lain, tidak sesuai dengan peruntukan harta wakaf seperti yang terdapat dalam akta ikrar wakaf, terjadi perubahan peruntukan harta wakaf; (6) Tidak ada persetujuan ahli waris, ahli waris tidak mengetahui apabila pewaris mewakafkan hartanya. Apabila ahli waris tidak menyetujui maka ada kemungkinan ahli waris akan menarik harta yang telah diwakafkan.

Pada tulisan ini akan diberikan dua contoh kasus sengketa wakaf yang diselesaikan melalui musyawarah dan mediasi. Pertama, tentang penarikan harta wakaf oleh ahli waris wakif (cucu) yang terjadi di kota Semarang dan upaya penyelesaiannya. Peristiwa ini terjadi pada tahun 2007, semula ada ahli waris wakif yang menuntut adanya penarikan kembali tanah Masjid Istiqomah yang berada di Kelurahan Wonolopo, Kecamatan Mijen, Kabupaten Semarang. Tanah wakaf yang didirikan Masjid Istiqomah tersebut luasnya sekitar $2000 \mathrm{~m}^{2}$, dan nadzirlah yang memelihara masjid tersebut. Pada suatu hari, cucu dari wakif datang ke KUA Kecamatan Mijen, menurutnya tanah wakaf yang dilakukan kakeknya tidak meliputi keseluruhan luas bidang tanah, melainkan hanya yang terbatas sebagai masjid saja. Menurut Bp. Agus Lathif (petugas PPAIW) memperkirakan bahwa tuntutan ahli waris wakif tersebut dikarenakan persoalan ekonomi (Latif, 2017).

Pihak PPAIW di KUA Kecamatan Mijen kemudian mengecek ke lapangan dan kelengkapan dokumentasi perbuatan wakaf yang dilakukan oleh wakif. Ternyata semua dokumen wakaf Masjid Istiqomah ditemukan lengkap, mulai AktaIkrar Wakaf (AIW) hingga sertifikat wakaf. Pihak KUA segera berkoordinasi dengan pihak Kalurahan Wonolopo yang menaungi wilayah tanah wakaf itu dan juga nadzir atau takmir masjid Istiqomah sebagai pemegang sertifikat tanah wakaf.

Setelah pihak takmir dan jamaah mengadakan musyawarah, mereka sepakat akan memberikan Dana Kerahiman sebanyak Rp. 10 juta kepada ahli waris wakif. Berikutnya pihak ahli waris wakif diundang oleh PPAIW untuk datang bersama dengan nadzir selaku takmir masjid Istiqomah, dan pihak Kalurahan Wonolopo untuk bermusyawarah menyelesaikan sengketa wakaf. Pada musyawarah tersebut diputuskan bahwa pihak ahli waris wakif diberikan dana kerahiman sebesar Rp 10 juta dari nadzir selaku takmir masjid Istiqomah dan membuat pernyataan. Isi pernyataan itu menegaskan pihak bahwa pihak ahli waris wakif tidak akan mempermasalahkan kembali status tanah wakaf yang pernah diberikan oleh kakeknya (Latif, 2017). Sengketa wakaf ini diselesaikan dengan menggunakan musyawarah yang dihadiri oleh para beberapa pihak untuk mencapai kesepakatan penyelesaian sengketa yang terjadi.

Kedua, contoh kasus sengketa wakaf pada tahun 2006, tentang perubahan substansi benda wakaf yang terjadi di Desa Bandengan, Kecamatan Kota Kendal, Kabupaten Kendal. Awalnya, bapak Razak, ketua RT setempat, mempunyai ide untuk membangun pos jaga malam (Pos Kamling) di lingkungannya. Pak Razak melihat lahan dekat masjid Ar-Rahman sangat strategis untuk dibangun pos kampling, kemudian Pak Razak dan beberapa warga meminta izin kepada takmir masjid Ar-Rahman berniat meminta sedikit lahan milik masjid guna 
dibangun pos kampling dengan alasan untuk kepentingan umum. Takmir mengijinkan pembangunan Pos Kamling dari tanah wakaf seluas 4x6 m, yang berada di sebelah barat masjid (Razak, 2017).

Pada mulanya pembangunan tersebut tidak ada masalah yang berarti, hanya beberapa selentingan ketidaksetujuan pembangunan Pos Kamling dibangun. Pada Tahun 2006, Munawir (ahli waris wakif), warga RT 11/03 Desa Bandengan merasa terusik dengan tanah masjid yang ditempati pos kampling. Munawir meminta penjelasan takmir atas pembangunan pos jaga itu, karena kakek Munawir, Khudlori (alm), dulu pernah mewakafkan tanah yang sekarang ditempati pos kampling (Munawir, 2017). Munawir sebagai ahli waris tidak terima, dia meminta takmir dan perangkat desa untuk menjelaskan dan menyelesaikan persoalan tersebut. Dengan demikian terjadilah sengketa wakaf antara ahli waris wakif dengan nadzir harta wakaf.

Sengketa wakaf di atas, akhirnya dimediasi oleh kepala desa Bandengan (Nasirun), di mana Pak Nasirun menjadi mediator antara takmir masjid Ar-Rahman yang diwakili Zubaidi dengan ahli waris wakif (Munawir). Pada mediasi tersebut Pak Munawir mengikuti pendapat sanak keluarganya, yang juga hali waris Khudlori, untuk meminta kepada Pak Razak sebagai ketua dan pengusung ide pembuatan Pos Kampling, mengganti tanah wakaf ayahnya seluas tanah yang telah digunakan. Berdasarkan kebijakan takmir, akhirnya Pak Razak dan warga RT yang dipimpinnya mengganti tanah tersebut, yaitu disebelah utara masjid meski lokasinya tidak dipinggir jalan. Sengketa wakaf di atas, diselesaikan dengan mediasi, yakni mempertemukan para pihak yang bersengketa dan menggunakan peran mediator untuk menyelesaiakannya. Hal ini disebabkan karena para pihak yang bersengketa tidak mempunyai kemampuan menyelesaikannya, dan para pihak bersepakat untuk meminta kepala desa menjadi mediator.

Bertitik tolak dari contoh sengketa wakaf di atas, dapat dipahami bahwa wakaf yang selalu berhubungan dengan kepentingan publik dan bernilai ekonomi, sangat rentan terjadinya sengketa. Sengketa mesti didahului dengan keluhan atau perasaan tidak puas oleh para pihak yang ada kaitannya dengan wakaf, seperti; ahli waris wakif, nadzir, dan masyarakat. Apabila keluhan tersebut tidak terselesaikan, akan menjadi masalah, bisa jadi masalah hukum apabila berkaitan dengan hukum. Jika para pihak menanggapinya dengan emosi, maka jadilah konflik, dan konflik yang tidak terselesaikan, akan menjadi sengketa yang memerlukan pihak lain untuk menyelesaikannya. Sengketa menjadi perkara apabila penyelesaiannya melalui jalur pengadilan (litigasi).

Data penelitian menunjukkan bahwa harta wakaf menjadi sebab pertama terjadinya konflik antara beberapa pihak yang terlibat dalam perbuatan wakaf. Para pihak tersebut adalah nadzir, wakif, ahli waris nadzir, dan ahli waris wakif. Pihak dominan yang sering terlibat sengketa wakaf adalah nadzir melawan ahli waris wakif, sebesar $67 \%$. Ahli waris wakif yang muncul pada sengketa wakaf di daerah obyek penelitian adalah anak dan atau cucu. Sikap ahli waris ini ada dua, yakni: Pertama, mendukung perbuatan wakaf wakif untuk menfungsikan harta wakaf supaya lebih bermanfaat di masyarakat, karena dapat mendatangkan pahala jariyah untuk orang tuanya, seperti; mengontrol dan mengevaluasi sejauh mana kinerja nadzir dalam mengelola dan memberdayakan harta wakaf, termasuk mensertifikatkan harta tanah wakaf.

Kedua, tidak mendukung perbuatan wakaf wakif, mereka berbuat tidak baik terhadap harta yang telah diwakafkan orang tuanya, apalagi kalau ahli waris kesulitan dalam hal ekonomi. Sikap yang dilakukan ahli waris yang tidak mendukung wakif berupa; mengambil kembali harta yang diwakafkan atau mengurangi harta wakif yang telah diwakafkan atau merebut kembali harta wakaf dari nadzir.

Pasal 62 UU Wakaf, menjelaskan bahwa penyelesaian sengketa wakaf dapat 
dilakukan melalui musyawarah untuk mencapai mufakat, apabila tidak berhasil, maka dapat diselesaikan melalui mediasi, arbitrase, atau pengadilan. Mediasi adalah penyelesaian sengketa dengan bantuan pihak ketiga (mediator) yang disepakati oleh para pihak yang bersengketa. Dalam hal mediasi tidak berhasil menyelesaikan sengketa, maka sengketa tersebut dapat dibawa kepada badan arbitrase syariah. Dalam hal badan arbitrase syariah tidak berhasil menyelesaikan sengketa, maka sengketa tersebut dapat dibawa ke pengadilan agama dan/atau mahkamah syar'iyah.

Penjelasan pasal ini lebih menfokuskan pada tata urutan penyelesaian sengketa wakaf. Apabila hal ini dikaitkan dengan model penyelesaian sengketa menurut hukum acara perdata, dikenallah model penyelesaian sengketa melalui jalur non litigasi (musyawarah dan mediasi) dan litigasi (akta perdamaian dan putusan hakim PA).

Metode penyelesaian sengketa wakaf yang digunakan oleh masyarakat wilayah Jawa Tengah Bagian Utara ada dua jalur, yakni: Pertama, jalur non litigasi, merupakan alternatif penyelesaian sengketa di luar pengadilan. Para pihak menganggap mekanisme penyelesaian sengketa non ligasi adalah upaya awal dalam penyelesaian sengketa wakaf, hal ini meliputi; (1) Musyawarah, yaitu penyelesaian sengketa dari para pihak yang terlibat sengketa, melalui proses atau kegiatan yang saling mendengar, menerima pendapat, dan keinginan yang didasarkan atas kesukarelaan di antara para pihak. Menurut hukum Islam, musyawarah disebut juga perdamaian (sulh), yaitu jenis akad untuk menyelesaikan atau mengakhiri sengketa (Anshoruddin, 2016). Penyelesaian sengketa wakaf melalui musyawarah terjadi pada kasus di Kecamatan Bonang Kabupaten Demak. (2) Mediasi, adalah penyelesaian sengketa melalui proses perundingan para pihak dengan dibantu oleh mediator.

Pelaksanaan mediasi dapat dilakukan melalui litigasi maupun non litigasi. Mediasi melalui litigasi dilaksanakan setelah sengketa wakaf menjadi perkara di Peradilan Agama dan hakim menunjuk mediator untuk menyelesaikan sengketa tersebut. Jika mediasi telah berhasil, maka dibuatlah akta perdamaian, namun apabila tidak berhasil, maka perkara tersebut diproses melalui hukum acara di persidangan. Mediasi melalui non litigasi dilaksanakan oleh para pihak yang bersengketa, setelah upaya musyawarah tidak berhasil, dan memerlukan pihak ketiga (mediator) untuk menyelesaikan sengketa wakaf. Mediator ini ditunjuk oleh para pihak yang bersengketa untuk mendamaikan mereka, seperti; pada kasus alih fungsi peruntukan harta wakaf di Kecamatan Patebon Kabupaten Kendal.

Kedua, jalur litigasi, adalah model penyelesaian sengketa wakaf melalui proses hukum dalam acara di Peradilan Agama. Produk hukum hakim PA adalah; (1) Akta Perdamaian, jika penyelesaian sengketa wakaf melalui mediasi di PA, seperti pada penyelesaian sengketa wakaf di Kecamatan Mranggen Demak; (2) Putusan hakim Peradilan Agama, jika penyelesaian sengketa sudah melalui hukum acara yang diputuskan oleh hakim Peradilan Agama, seperti; Putusan PA Semarang tentang Kedudukan Hukum Pengambilalihan Tanah Wakaf yangBatal Demi Hukum Untuk Dibagikan Sebagai Harta Warisan.

Jika dikaitkan dengan hasil penelitian di atas, pada tabel 2 dijelaskan tentang diskripsi kasus wakaf dan penyelesaiannya, maka dapat dijelaskan bahwa penyelesaian sengketa wakaf pada penelitian ini lebih banyak menggunakan jalur non litigasi, yakni musyawarah (23\%) dan mediasi $(60,8 \%)$. Jalur non litigasi merupakan alternatif penyelesaian sengketa dengan melibatkan para pihak yang bersengketa, tanpa melalui proses peradilan. Jalur non litigasi ada dua, yakin melalui musyawarah dan mediasi.

Musyawarah merupakan penyelesaian sengketa dari para pihak yang terlibat dalam sengketa, yang diawali dengan mendengarkan keluhan pihak yang merasa dirugikan, kemudian dijawab oleh pihak lain yang menyebabkan sengketa wakaf terjadi. 
Setelah para pihak saling mendengar dan menjawab keluhan yang terjadi, kemudian mereka bersama-sama menemukan penyelesaiannya melalui kesepakatan dan saling merelakan atau saling berlapang dada. Penyelesaian dengan cara ini merupakan penyelesaian yang mudah, sederhana, murah, dan terjamin kerahasiaannya. Selain itu, penyelesaian sengketa wakaf yang diselesaikan dengan musyawarah, biasanya terjadi pada masalah sederhana, karena para pihak mempunyai daya toleransi tinggi untuk menyatukan atau mencari persamaan dari perbedaan pendapat demi terselesaikannya sengketa wakaf, sehingga menimbulkan hubungan baik pasca sengketa.

Pada penelitian ini, menunjukkan bahwa penyelesaian sengketa wakaf melalui musyawarah terjadi pada kasus wakaf pada tahun 2015 di Kecamatan Bonang Kabupaten Demak. Kasus wakaf tersebut tentang sengketa wakaf yang disebabkan ahli waris tidak setuju apabila orang tuanya berwakaf tanah dan ada keinginan ahli waris untuk mengambilnya. Selain itu, juga pada kasus wakaf tentang berubahnya peruntukan harta wakaf yang tidak sesuai dengan akta ikrar wakaf yang terjadi pada tempat dan tahun yang sama. Menurut peneliti, para pihak menyelesaikan sengketa wakaf dengan musyawarah dikarenakan adanya keinginan bersama untuk menjaga amanah wakif supaya wakaf berjalan sesuai dengan peraturan dan dapat menimbulkan kemashlahatan pada semua pihak, seperti; wakif, nadzir, ahli waris wakif, dan masyarakat.

Pada penelitian ini, menunjukkan bahwa banyak ditemukan kasus sengketa wakaf yang upaya penyelesaiannya tidak hanya dilakukan oleh beberapa pihak yang terlibat dalam sengketa saja, namun melibatkan pihak lain (mediator) untuk membantu menyelesaian sengketa wakaf, hal inilah yang disebut mediasi. Mediasi merupakan alternatif penyelesaian sengketa melalui proses perundingan para pihak yang dibantu oleh mediator. Mediasi menjadi alternatif penyelesaian sengketa apabila para pihak tidak berhasil menyelesaikan sengketa wakaf dengan cara damai atau musyawarah, para pihak meminta bantuan mediator untuk membantu menyelesaikan sengketa wakaf. Fungsi mediator dalam proses mediasi, selain sebagai penengah atau wasit, juga memberikan alternatif pilihan penyelesaian sengketa menuju pada kesepakatan kedua belah pihak dan pelaksanaan kesepakatan tersebut (Sari, 2017).

Data penelitian menjelaskan bahwa sebagian besar penyelesaian sengketa wakaf menggunakan alternatif mediasi $(60,8 \%)$, karena mediasi mempunyai beberapa kelebihan, yakni; proses lebih cepat, biaya lebih murah, sifatnya informal dan final, kerahasiaan terjamin, dapat menjaga hubungan baik, ada kebebasan memilih pihak ketiga, pelaksanaan tatap muka yang pasti, lebih mudah melakukan perbaikan, dan tata cara penyelesaian sengketa diatur oleh para pihak yang bersengketa.

Data penelitian primer wakaf menunjukkan bahwa penyelesaian sengketa wakaf yang terjadi di Jawa Tengah Bagian Utara, sedikit menggunakan jalur litigasi melalui PA, hanya $1,9 \%$. Beberapa hal yang menyebabkan para pihak yang bersengketa wakaf tidak memilih menyelesaikan sengketa wakaf melalui jalur litigasi adalah: proses penyelesaian sengketa berjalan terlalu formal dan kaku, tidak fleksibel, proses peradilan lebih banyak menjangkau aspek hukum saja, sedikit memperhatikan aspek psikis dan sosiologis, hakim cenderung menempatkan para pihak sebagai obyek harus diperiksa dan diadili, hakim mendominasi dalam proses peradilan, putusan hakim cenderung bersifat formal, karena hanya memperhatikan aspek hukum formil yang berdasarkan doktrin dan teks undang-undang, memakan waktu yang lama, dari pendaftaran, pemanggilan para pihak, pemeriksaan, pembuktian, dan seterusnya, menghabiskan biaya banyak, ada yang kalah dan ada yang menang, faktor waktu dan tempat yang jauh (Musytar, 2017).

Metode penyelesaian sengketa wakaf melalui alternatif penyelesaian arbritase tidak ada, karena arbritase biasanya 
digunakan dalam penyelesaian kasus sengketa di bidang perdagangan. Pada sengketa tanah wakaf, sejauh ini, tidak ada kaitannya dengan perdagangan, karena mayoritas masyarakat pesisir Jawa Tengah memahami bahwa harta wakaf itu berupa tanah dan tidak diberdayakan secara produktif.

Berdasarkan analisis di atas, dapat dirumuskan bahwa penyelesaian sengketa wakaf yang terjadi di Jawa Tengah Bagian Utara ternyata menggunakan metode yang sesuai dengan Pasal 62 UU Wakaf, yakni jalur litigasi dan non litigasi melalui musyawarah dan mediasi. Pada penelitian ini, para pihak yang bersengketa tidak menggunakan metode penyelesaian arbritase, karena obyek yang disengketakan adalah harta wakaf berupa benda tetap (tanah).

\section{Simpulan}

Berdasarkan paparan penjelasan di atas dapat disimpulkan bahwa penyelesaian sengketa wakaf yang terjadi di daerah Jawa Tengah Bagian Utara menggunakan metode yang sesuai dengan Pasal 62 UU Wakaf, yakni jalur litigasi dan non litigasi melalui musyawarah dan mediasi. Para pihak lebih banyak menggunakan alternatif penyelesaian sengketa melalui jalur non litigasi yang berupa musyawarah $(23,3 \%)$ dan mediasi $(60,8)$. Musyawarah digunakan pada sengketa wakaf yang sederhana dan sangat cocok diterapkan pada masyarakat yang punya daya kekerabatan dan toleransi tinggi, masyarakat komunal yang selalu menjaga kerukunan, kebersamaan, dan persaudaraan. Alternatif penyelesaian sengketa wakaf melalui jalur mediasi paling banyak digunakan para pihak yang bersengketa $(60,8 \%)$. Mediasi menjadi alternatif penyelesaian sengketa apabila musyawarah tidak bisa dilaksanakan.

\section{DAFTAR PUSTAKA}

Abdullah, J.; N. Q. (2014). Penyelesaian Sengketa Wakaf dalam Hukum Positif. Jurnal ZISWAF, 1(1), 51-52.
Anshoruddin. (2016). Penyelesaian Sengketa Perwakafan Di Indonesia Dalam Perspektif Hukum Islam Dan Hukum Nasional. Seminar, Disampaikan dihadapan Pengurus Masjid Majlis Ta'lim dan Pengelola Pondok Pesantren Se KALBAR berkaitan dengan kergiatan Kanwil Kemenag Kalbar: Sosialisasi ttg Wakaf.

Fadhilah, N. (2011). Sengketa Tanah Wakaf dan Strategi Penyelesaiannya. De Jure Jurnal Syariah Dan Hukum, 3(1), 7880.

Hafsah. (2009). Wakaf Produktif Dalam Hukum Islam Indonesia Analisis Filosofis Terhadap Undang-Undang RI No. 41 Tahun 2004 Tentang Wakaf. MIQOT Jurnal Ilmu-Ilmu Keislaman, 33(1), 5.

Harahap, S. (n.d.). Paradigma Baru Wakaf, Jakarta.

Hendrawati, D. ; I. (2018). Penyelesaian Sengketa Tanah Wakaf Yang Tidak Tersertifikasi di Wilayah Pesisir Jawa Tengah, FH UNDIP. Jurnal MasalahMasalah Hukum, 1(1), 77.

Heniyatun dkk. (2017). Kajian Yuridis Peralihan Hak Cipta Sebagai Objek Wakaf. Jurnal Hukum Novelty, 8(1), 102.

Latif, A. (2017). Wawancara Pejabat PPAIW Kecamatan Mijen melalui media sosial 13 November 2017 jam 13.00. WIB. Semarang.

Munawir. (2017). Wawancara Ahli Waris Wakif di Masjid Ar-Rahman Bandengan Kabupaten Kendal pada tanggal 12 November 2017 jam 15.00-17.00 WIB. Kendal.

Musytar. (2017). Wawancara dengan Hakim Pengadilan Agama Kendal, Selasa, 28 Oktober 2017, jam 09.00-11.00 WIB.

Razak. (2017). Wawancara Ketua RT 10/03 Desa Bandengan Kecamatan Kota Kendal melalui Media Sosial pada 
tanggal 20 September 2017 jam 15.0017.00 WIB. Kendal.

Sabiq, S. (1994). Fiqh al-Sunnah. Beirut: Dar al-Fikr.

Sari, S. W. (2017). Implementasi Peraturan Mahkamah Agung Nomor 1 Tahun 2016 tentang Prosedur Mediasi di Pengadilan dan Undang-Undang Nomor 30 Tahun 1999 Tentang Arbitrase dan Alternatif Penyelesaian Sengketa (Studi Kasus Sengketa Wakaf di Pengadilan Agama Tulungagung Jawa Timur.

Siregar, I. (2012). Penyelesaian Sengketa Wakaf Di Indonesia: Pendekatan Sejarah Sosial Hukum Islam. Miqot Jurnal Ilmu-Ilmu Keislaman, 36(1), 1.

Soekanto, S. (1985). Pengantar Penelitian Hukum. Jakarta: UI Press.

Subagyo, P. J. (1991). Metode Penelitian dalam Teori dan Praktek. Jakarta: Rineka Cipta. 